\title{
Cytomegalovirus Viral Load Measurement
}

National Cancer Institute

\section{Source}

National Cancer Institute. Cytomegalovirus Viral Load Measurement. NCI Thesaurus.

Code C98716.

The determination of the amount of cytomegalovirus viral load present in a sample. 